\title{
EFFECT OF CULTURE CONDITIONS FOR ANTIMICROBIAL ACTIVITY OF MARINE - DERIVED FUNGUS ASPERGILLUS FLOCCULOSUS 01NT.1.1.5
}

\author{
Phan Thi Hoai Trinh ${ }^{1,3,}$, Ngo Thi Duy Ngoc ${ }^{1}$, Vo Thi Dieu Trang ${ }^{1}$, Phi Quyet Tien ${ }^{2,3}$, Bui Minh Ly ${ }^{1,3}$, \\ Tran Thi Thanh Van ${ }^{1,3}$, Pham Duc Thinh ${ }^{1,3}$, Pham Trung San ${ }^{1,3}$ \\ ${ }^{1}$ Nha Trang Institute of Technology Research and Application, Vietnam Academy of Science and Technology \\ ${ }^{2}$ Institute of Biotechnology, Vietnam Academy of Science and Technology \\ ${ }^{3}$ Graduate University of Science and Technology, Vietnam Academy of Science and Technology \\ ${ }^{凶}$ To whom correspondence should be addressed. E-mail: phanhoaitrinh84@gmail.com
}

Received: 05.9.2017

Accepted: 25.12.2017

\section{SUMMARY}

The biosynthesis of compounds with antibiotic activity produced by marine fungi, strongly depends on their growth conditions. A good understanding of the role of culture conditions in the biosynthesis of metabolites may lead to better exploitation of microbial metabolites. In this study, the influence of culture conditions including incubation period, initial $\mathrm{pH}$ and salinity on antimicrobial activity and secondary metabolites production of marine fungus 01NT.1.1.5 was investigated. This isolate, obtained from sponge Stylissa sp. in Nha Trang Bay, exhibited a broad spectrum of in vitro antimicrobial activity to Bacillus cereus ATCC 11778, Escherichia coli ATCC 25922, Staphylococcus aureus ATCC 25923, Listeria monocytogenes ATCC 19111, Streptococcus faecalis ATCC 19433 and Candida albicans ATCC 10231. According to morphological characteristics and sequence analysis of $28 \mathrm{~S}$ rDNA, the fungus was identified as Aspergillus flocculosus. The results indicated that antimicrobial activity and metabolite amount were highest when the fungus was cultivated in rice medium with incubation period of 20 days. The optimum salinity of $35 \mathrm{~g} / \mathrm{L}$ and initial $\mathrm{pH}$ of 6.0 were found for the maximum antibiotic production. The colony growth, antimicrobial activity and production of secondary metabolites of the strain A. flocculosus 01NT.1.1.5 varied depending on salt concentrations and initial $\mathrm{pH}$ of medium. Particularly, extract of this fungus only showed activity against $C$. albicans when it was cultured in medium with $30-35 \mathrm{~g} / \mathrm{L}$ salinity and initial $\mathrm{pH} 4.0-8.0$. The results indicate that salinity and initial $\mathrm{pH}$ along with cultivation period are important factors influencing antimicrobial activity and secondary metabolites of $A$. flocculosus 01 NT.1.1.5, and might be for other marine fungi.

Keywords: Aspergillus flocculosus, antimicrobial activity, culture conditions, marine fungi

\section{INTRODUCTION}

In recent years, wide dissemination and emergence of multi-drug resistant bacteria have been concerned as great impact to public health. The rise in antibiotic resistance has been threatening to modern healthcare (Kalyani et al., 2016; Wang et al., 2011). Therefore, finding new antimicrobial agents, especially those from natural resources as well as biotechnological manipulation to increase their activities have been strongly pursued to develop efficient cure methods for treatment of infectious diseases. Marine fungi have been reported as potential sources of novel metabolites with bioactivities such as antibiotics, antiviral, anticancer and antioxidant (Saleem et al., 2007; Du et al., 2014).
Particularly, fungal species belonging to the genus Aspergillus are ones of the major microbial sources of variety of compounds with antimicrobial activity (Li, 2010; Petersen et al., 2015). The antimicrobial potential of Aspergillus spp. against a panel of bacterial and fungal pathogens has been reported (Maria et al., 2005).

The production of antibiotics by microorganisms, including filamentous fungi can be enhanced by the nutritional factors such as carbon and nitrogen sources, inorganic salts with various cultivation factors, temperature, $\mathrm{pH}$, incubation period (Barakat, Gohar, 2012). Optimization of culture conditions can impact the quantity and diversity of metabolic products of microbes and thus frequently has been 
applied for the discovering new natural bioactive compounds (Bills et al., 2008).

Aspergillus flocculosus 01NT.1.1.5, a marine fungus isolated from sponge Stylissa sp. at Nha Trang Bay. Our previous study showed that the fungus has considerable antimicrobial activity against a panel number of clinically significant pathogens. In present study, we conducted the effect of culturing conditions for this isolate in order to get the highest antibiotic production.

\section{MATERIALS AND METHODS}

\section{Fungal isolate}

The fungus $A$. flocculosus 01NT.1.1.5 was originally isolated from sponge Stylissa sp., which was collected at Nha Trang Bay, Vietnam, in February 2016. The fungus was identified according to its gene sequence of $28 \mathrm{~S}$ rDNA. The genomic DNA of the isolate was extracted using a FastDNA spin kit for soil (Bio 101 Systems or Q-Bio gene) by following the company's protocol. DNA was amplified using primers NL209 (5'AAGCGCAGGAAAAGAAACCAACAG-3') and NL912 (5'-TCAAATCCATCCGAGAACATCAG3'), purified with a Geneclean III kit (Q-Bio gene), and sequenced using the fluorescent method and a Li-COR 4200 DNA sequencer (Amodia Bioservice $\mathrm{GmbH}$, Braunschweig, Germany) (Zuccaro et al., 2008). For identification, the sequence of the fungal $28 \mathrm{~S}$ rDNA region were compared with those in the NCBI (National Center for Biotechnology Information; http:/www.ncbi.nlm.nih.gov). The strain was stocked in sterile seawater with $40 \%$ glycerol at $-80{ }^{\circ} \mathrm{C}$ in the Marine Microorganism Collection at Nha Trang Institute of Technology Research and Application (NITRA).

Cultural and morphological properties of $\operatorname{strain} A$. flocculosus 01NT.1.1.5

The cultural properties and morphological features of the spores and mycelia of strain $A$. flocculosus 01NT.1.1.5 were examined on Czapek medium (saccharose $30 \mathrm{~g}, \mathrm{NaNO}_{3} 3 \mathrm{~g}, \mathrm{~K}_{2} \mathrm{HPO} 41 \mathrm{~g}$, $\mathrm{MgSO}_{4} 0.5 \mathrm{~g}, \mathrm{KCl} 0.5 \mathrm{~g}, \mathrm{FeSO}_{4} 0.1 \mathrm{~g}$, agar $15 \mathrm{~g}$, seawater $1000 \mathrm{~mL}$ ) after culturing at $28^{\circ} \mathrm{C}$ for 10 days (Vandermolen et al., 2013). The conidiophores and conidia were observed with a B204 series biological microscope (Chongqing Optec Instrument Co., Ltd., Chongqing, China).

\section{Antimicrobial assay}

Antibacterial activity of ethyl acetate extracts from the marine fungus was determined against pathogens using disc diffusion assay (Becerro et al., 1994). The crude extracts were impregnated at a concentration of $100 \mu \mathrm{g} / \mathrm{disc}$ on to $6 \mathrm{~mm}$ diameter sterile Whatman No1. discs and allowed to dry in the air at room temperature for solvent evaporation. The antimicrobial activity was assessed against six pathogens, including $B$. cereus ATCC 11778 , E. coli ATCC 25922, $S$. aureus ATCC 25923, $L$. monocytogenes ATCC 19111, S. faecalis ATCC 19433 and $C$. albicans ATCC 10231. The test microorganisms were grown on nutrient agar media and their density was adjusted to standard McFarland 0.5 using a spectrophotometer at a wavelength of $625 \mathrm{~nm}$. Ethyl acetate without extracts in the discs was used as negative control. The plates were incubated at $37{ }^{\circ} \mathrm{C}$ for 24 hours and results were recorded as zone of inhibition in $\mathrm{mm}$.

\section{Effect of culture conditions for antimicrobial activity}

The fungal strain was grown stationary at $28{ }^{\circ} \mathrm{C}$ in $500 \mathrm{ml}$ Erlenmeyer flasks, each containing $40 \mathrm{~mL}$ of natural seawater collected in Nha Trang Bay $(\mathrm{pH}$ 8.0 , salinity of $30 \mathrm{~g} / \mathrm{L}$ ) supplemented with $20 \mathrm{~g}$ of rice, $20 \mathrm{mg}$ of yeast extract, $10 \mathrm{mg}$ of $\mathrm{KH}_{2} \mathrm{PO}_{4}$ (Sobolevskaya et al., 2016). Effects of culture conditions on antimicrobial activity were investigated separately for each parameter (i.e. incubation period, $\mathrm{pH}$ and salinity). At the end of the incubation period, mycelia and media were homogenized and extracted two times with equal volume of ethyl acetate. The extracts were then concentrated by using rotary evaporator at $40{ }^{\circ} \mathrm{C}$ and used as crude extracts for the test of antimicrobial activity. Thus, growth time-dependent antimicrobial activity of the fungus was studied by growing it in rice media with cultivation time from 8 to 20 days with two day intervals. The effect of salinity was investigated at concentrations from 5 to $40 \mathrm{~g}$ sea salt/L (with intervals of $5 \mathrm{~g}$ sea salt/L) and initial culture medium $\mathrm{pH}$ from 4.0 to 9.0 .

\section{RESULTS AND DISCUSSION}

Morphological characterizations and identification of the strain 01NT.1.1.5

The fungal strain 01NT.1.1.5 was cultured on Czapek medium for observation of morphological 
characterization. After ten days of growth at $28^{\circ} \mathrm{C}$, the fungus had colonies of about $20 \mathrm{~mm}$ in diameter, white to greyish white aerial mycelial, light yellow to olive to brownish orange sporulation, reddish brown soluble pigment in conspicuous and yellowish olive exudate. Observation under light microscopy revealed radiating conidial heads, biseriate conidiophores, yellow to brown hyaline stipes and globose vesicles (Figure 1).

Combination of macroscopic and microscopic characteristics and molecular methods remain commonly used and essential tools for identification of Aspergillus species (Samson et al., 2014). The 28S rDNA sequence region (796 bp) was amplified by PCR and sequenced; BLAST search results indicated similarity to the sequence of Aspergillus flocculosus NRRL 5224 (GenBank accession number EU021616.1) with a $100 \%$ identity. Moreover, the observed morphological characteristics of this fungus are similar to features of Aspergillus flocculosus those were decribed by Samson et al., (2014). Thus, the fungal strain 01NT.1.1.5 was assigned the name Aspergillus flocculosus 01NT.1.1.5.

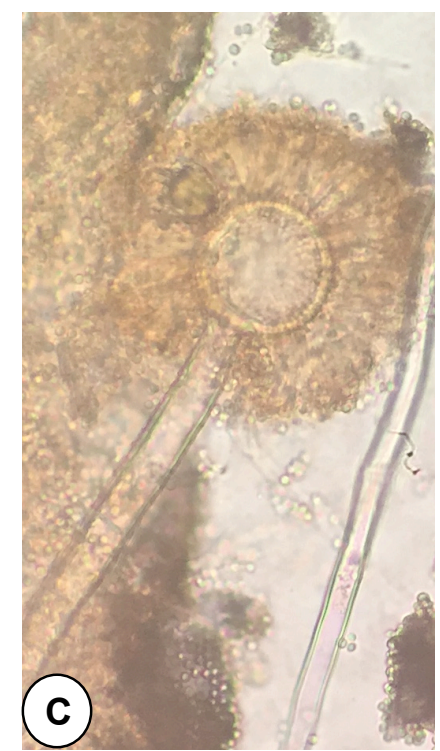

Figure 1. Colony appearance and micromorphology of $A$. flocculosus 01NT.1.1.5. and the sample of the sponge Stylissa sp. (A) Sample of the sponge Stylissa sp.; (B) Colony appearance after ten days on Czapek medium; (C) Conidiophores and conidia after ten days.

\section{Effect of culturing conditions on antimicrobial activity of $A$. flocculosus 01NT.1.1.5}

In this study, three parameters including incubation period, initial $\mathrm{pH}$ and salinity were investigated to achieve maximum antimicrobial activity and high yield of metabolite production by the fungal strain A. flocculosus 01NT.1.1.5.

\section{Effect of incubation period}

Antimicrobial metabolite production by this marine fungus was determined over a period of 26 days. The bioactive metabolite production increased from the $12^{\text {th }}$ day, reaching the highest level on $20^{\text {th }}$ day of incubation, then declined gradually (Figure 2). Therefore, 20 day incubation was selected for the fungus to reach maximum production of antimicrobial metabolites.

Generally fungal strains have different optimal culturing time for growth and synthesis of bioactive compounds. Particularly, the marine fungus Aspergillus terreus var. africanus showed optimal growth time with high antimicrobial activity at the $6^{\text {th }}$ day (Barakat and Gohar, 2012). Similarly, production of bioactive compounds by marine fungus Cladosporium sphaerospermum was increased gradually until reached the maximum level after 8 days, then decreased (Kalyani et al., 2016). However, Mabrouk et al., (2011) reported that the marine fungus Penicillium brevicompactum, associated algae Pterocladia sp., showed maxium bioactivity after 12 days of cultivation. 

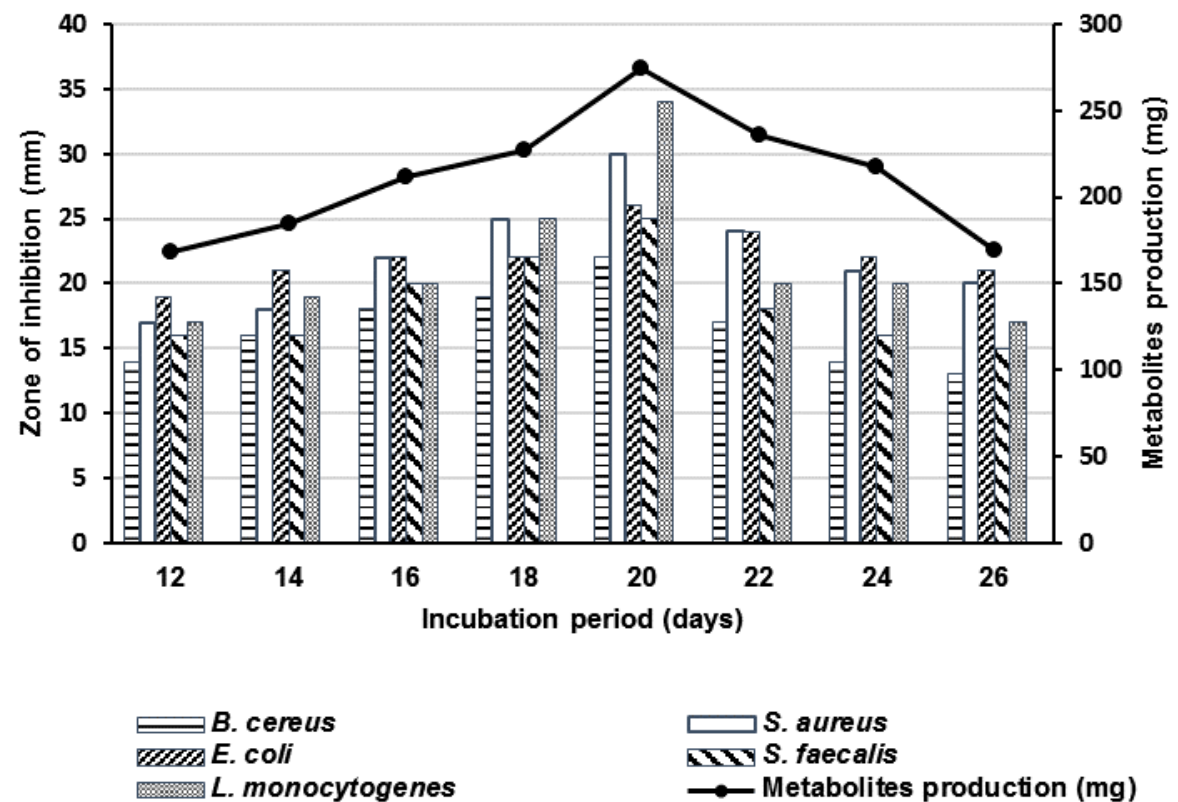

Figure 2. Effect of incubation period on antimicrobial activity and metabolites production.

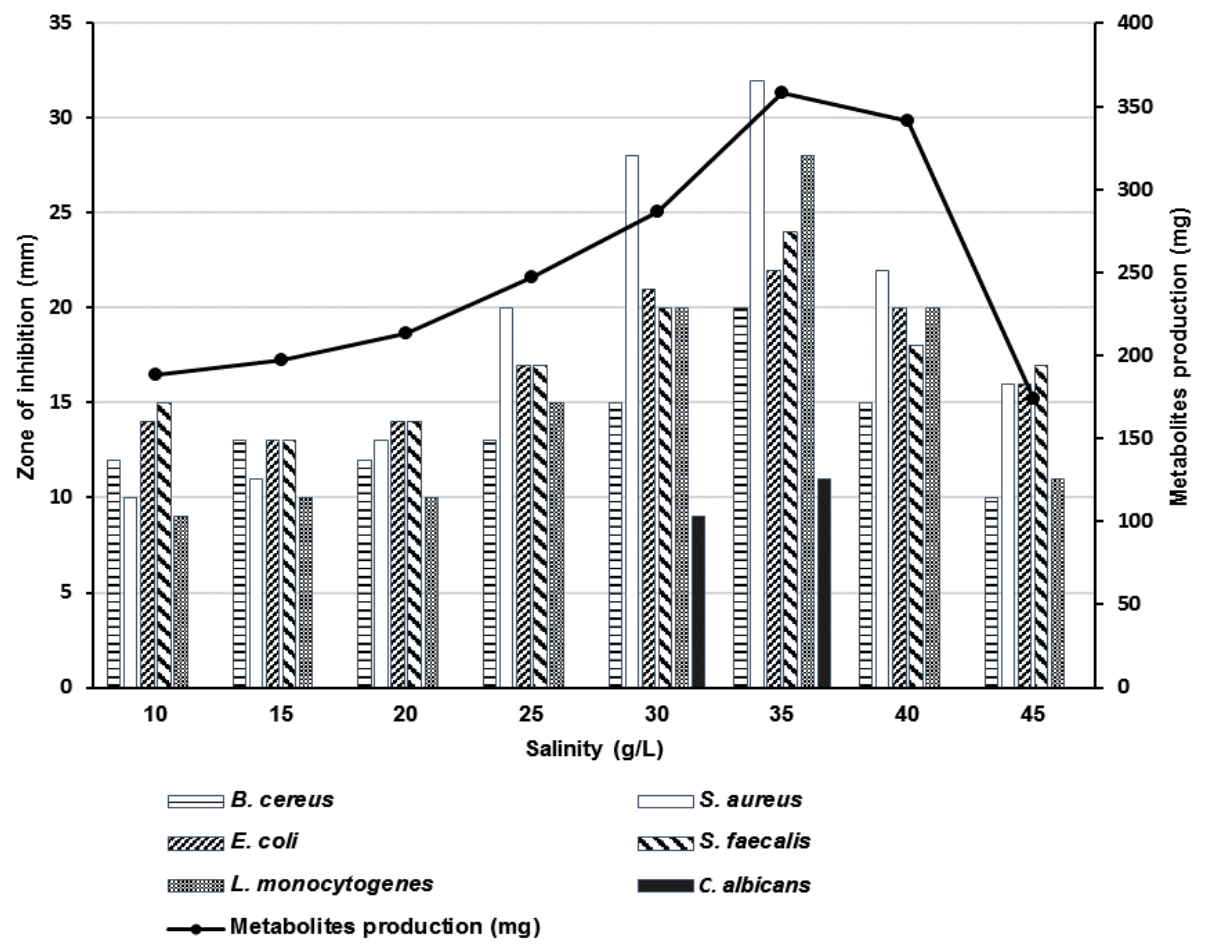

Figure 3. Effect of salinity on antimicrobial activity and metabolites production. 
The differences in optimal incubation period for biosynthesis of bioactive compounds in many fungi might be due to different ecological characteristics and growth media as well. In particular, most of the strains reported were inoculated in broth medium with shaking. In our study, the isolate $A$. flocculosus 01NT.1.1.5 was cultured in semi-solid medium with static state. This could be the reason leading to a longer time for growth and biosynthesis of antibacterial compounds.

\section{Effect of salinity}

Growth and metabolite production by fungi, especially marine fungi are largely affected by salt concentration in the culturing media (Jingjing et al., 2011). In our study, different concentrations of salt in the growth medium were tested. The results showed that strain A. flocculosus 01NT.1.1.5 obtained the highest antimicrobial activity and metabolite production at salinity of $35 \mathrm{~g} / \mathrm{L}$ (Figure 3 ). Only at the salinity of 30 to $35 \mathrm{~g} / \mathrm{L}$ this isolate had inhibitory effects against $C$. albicans, whereas at other salt concentrations this property was not observed. The higher salt concentration, the more rapid decrease of metabolite production by the strain A. flocculosus 01NT.1.1.5.

Several authors reported that $\mathrm{NaCl}$ concentration of $30 \mathrm{~g} / \mathrm{L}$ was the optimal for maximum mycelia weight and antibacterial metabolite production (Kalyani et al., 2016). Miao et al., (2006) reported that medium at $34 \mathrm{~g} / \mathrm{L}$ salt was the best condition for active metabolite production by the strain $A$. saccharicola. Beside, $\mathrm{NaCl}$ concentration of $3.0 \%$ was also found to be optimum for maximum growth and production of bioactive metabolite by an fungus, Fusarium sp. (Gogoi et al., 2008). Similarly, the marine fungus Penicillium chrysogenum was investigated by Trinh et al., (2016) and suggested that the fungal strain showed highest antimicrobial activity in rice medium at salinity of $35 \mathrm{~g} / \mathrm{L}$. Cantrell et al., (2006) found that the marine fungi with dark cell wall can tolerate higher salinity than the moniliaceous fungi. According to Jingjing et al. (2011), the habitats of marine fungi had a strong influence on their adaptation to salt.

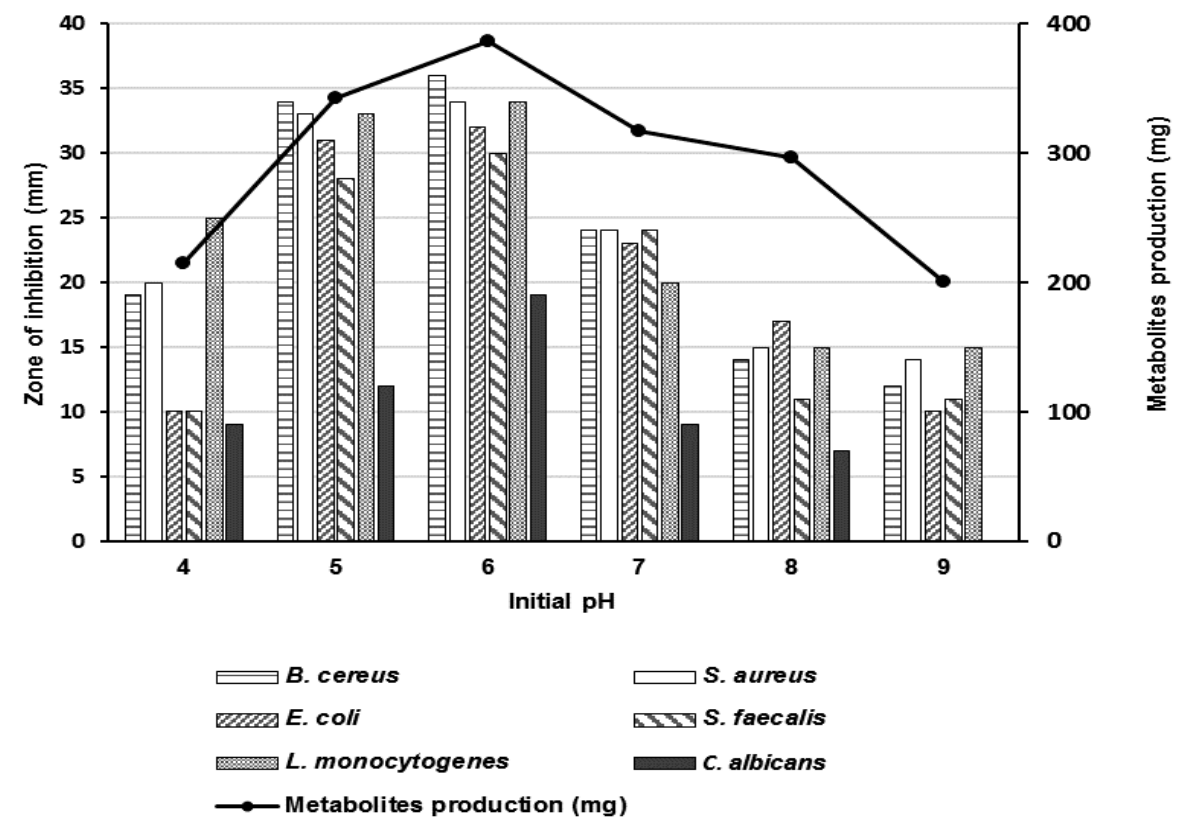

Figure 4. Effect of initial $\mathrm{pH}$ on antimicrobial activity and metabolites production.

\section{Effect of initial $\mathrm{pH}$}

$\mathrm{pH}$ values regarding to hydrogen or hydroxyl ion concentration may affect directly on cell, or indirectly on a degree of dissociation of substances in the medium. Therefore, initial $\mathrm{pH}$ of the culture medium affects not only growth but also antimicrobial agent production (Singh et al., 2017).

In the present study, different initial $\mathrm{pH}$ values 
were experimentally tested. It has been observed that maximum antibiotic activity was obtained at $\mathrm{pH} 6.0$ by A. flocculosus 01NT.1.1.5 and beyond the optimum $\mathrm{pH}$ the antimicrobial activity decreased (Figure 4). Low yield of metabolite and inactivation towards $C$. albicans was showed at $\mathrm{pH} 9.0$.

Similar results were reported by Mabrouk et al. (2008), i.e. initial $\mathrm{pH}$ of the medium suitable for marine fungus Varicosporina ramulosa to get the highest bioactivity was $\mathrm{pH}$ 6.0. In another study, Jain and Pundir (2011) showed that the maximum antimicrobial activity of $A$. terreus against pathogens was also found at $\mathrm{pH}$ 6.0. Nevertheless, a more alkaline optimum $\mathrm{pH}$ of 7.5 was reported for antibacterial activity by marine-derived fungus Arthrinium saccharicola isolated from seawater in Yung Shue O, Hong Kong (Miao et al., 2006). The culture medium $\mathrm{pH}$ is usually not constant throughout fungal growth and the changes might affect the metabolite synthesis to a certain extension (Daryaei et al., 2016; Padhi et al., 2017).

Nowadays, the emergent drug resistance among pathogenic microorganisms, increasing the rate of microbial infections has been attracting much of public concern (Singh et al., 2015). Discovering new and effective antimicrobial substances from varied natural resources, including microorganisms is an approach to overcome the problem.

Production of antimicrobial agents is often influenced by nutritional as well as cultivation factors, which are considered as important parameters for scale-up process in industrial production. The optimal culture conditions for the strain A. flocculosus 01NT.1.1.5 showed in this study could be the first steps in study on scaling up the production process (Bills et al., 2008).

\section{CONCLUSIONS}

Our studies showed that A. flocculosus 01NT.1.1.5, a marine fungus isolated from sponge Stylissa sp., had optimum culture conditions for biosynthesis of antimicrobial metabolites in rice medium with salinity of $35 \mathrm{~g} / \mathrm{L}$, initial $\mathrm{pH} 6.0$ after 20 days of incubation. The results also indicated that culture medium had a strong influence on antibiotic activity of the isolate. Further studies on optimization of nutritional composition for bioactivity and metabolite production by the strain will be carried out.
Acknowledgments: This study was supported by the Grant of RV “Akademik Oparin” expedition, (VAST. HTQT.NGA.15-06/16-17).

\section{REFERENCES}

Barakat KM, Gohar YM (2012) Antimicrobial agents produced by marine Aspergillus terreus var. africanus against some virulent fish pathogens. Indian $J$ Microbiol 52(3): 366-372.

Beccerro MA, Lopez NI, Turon X, Uriz MJ (1994) Antimicrobial activity and surface bacterial film in marine sponges. J Exp Mar Biol Ecol 179(2): 195-205.

Bills GF, Platas G, Fillola A, Jimenez MR, Collado J, Vicente F (2008) Enhancement of antibiotic and secondary metabolite detection from filamentous fungi by growth on nutritional arrays. J Appl Microbiol 104(6): 1644-1658.

Cantrell S A, Casillas-Martinez L, Molina M (2006) Characterization of fungi from hypersaline environments of solar salterns using morphological and molecular techniques. Mycol Res 110(Pt 8): 962-970.

Daryaei A, Jones EE, Glare TR, Falloon RE (2016) pH and water activity in culture media effect biological control activity of Trichoderma atroviride against Rhizoctonia solani. Biol Control 92: 24-30.

Du FY, Zhang P, Li XM, Li CS, Cui CM, Wang BG (2014) Cyclohexadepsipeptides of the isaridin class from the marine-derived fungus Beauveria felina EN-135. J Nat Prod 77(5): 1164-1169.

Gogoi DK, Deka Boruah HP, Saikia R, Bora TC (2008) Optimization of process parameters for improved production of bioactive metabolite by a novel endophytic fungus Fusarium sp. DF2 isolated from Taxus wallichiana of North East India. World J Microbiolv Biotechnol 24(1): 79-87.

Jain P, Pundir RK (2011) Effect of fermentation medium, $\mathrm{pH}$ and temperature variations on antibacterial soil fungal metabolite production. J Agric Technol 7(2): 247-269.

Jingjing H, Chunhua L, Xiaoming Q, Yaojian H, Zhonghui Z, Yuemao S (2011) Effect of salinity on the growth, biological activity and secondary metabolites of some marine fungi. Acta Oceanol Sin 30(3): 118-123.

Kalyani P, Geetha S, Hemalatha KPJ (2016) Optimization of cultural conditions for improved production and bioactive metabolites by Aspergillus niger (MTTC-961). EJPMR 3(10): 255-260.

Li SM (2010) Prenylated indole derivatives from fungi: structure diversity, biological activities, biosynthesis and chemoenzymatic synthesis. Nat Prod Rep 27(1): 57-58.

Mabrouk AM, Kheiralla ZH, Hamed ER, Youssry AA, Abd El Aty AA (2008) Production of some biologically 
active secondary metabolites from marine-derived fungus Varicosporina ramulosa. Malays J Microbiol 4(1): 14-24.

Mabrouk AM, Kheiralla ZH, Hamed ER, Youssry AA, Abd El Aty AA (2011) Physiological studies on some biologically active secondary metabolites from marinederived fungus Penicillium brevicompactum. 1: 1-15http.

Maria GL, Sridhar KR, Raviraja NS (2005) Antimicrobial and enzyme activity of mangrove endophytic fungi of southwest coast of India. J Agric Technol 1: 67-80.

Miao L, Kwong TF, Qian PY (2006) Effect of culture conditions on mycelial growth, antibacterial activity, and metabolite profiles of the marine-derived fungus Arthrinium c.f. saccharicola. Appl Microbiol Biotechnol 72(5): 1063-1073

Padhi S, Das D, Panja S, Tayung K (2017) Molecular characterization and antimicrobial activity of an endolichenic fungus, Aspergillus sp. isolated from parmelia caperata of similipal biosphere reserve, India. Interdiscip Sci 9(2): 237-246.

Petersen LM, Kildgaard S, Jaspars M, Larsen TO (2015) Aspiperidine oxide, a piperidine $\mathrm{N}$-oxide from the filamentous fungus Aspergillus indologenus. Tetrahedr Lett 56(14): 1847-1850.

Phan Thi Hoai Trinh, Ngo Thi Duy Ngoc, Phi Quyet Tien, Bui Minh Ly, Tran Thi Thanh Van (2016) Effect of cultural conditions on antimicrobial activity of marine derived fungus Penicillium chrysogenum. Vietnam $J$ Biotechnol 14(4): 1-7.

Saleem M, Ali MS, Hussain S, Jabbar A, Ashraf M, Lee YS (2007) Marine natural products of fungal origin. Nat Prod Rep 24(5): 1142-1152.

Samson RA, Visagie CM, Houbraken J, Hong SB, Hubka
V, Klaassen CH, Perrone G, Seifert KA, Susca A, Tanney JB, Varga J, Kocsubé S, Szigeti G, Yaguchi T, Frisvad JC (2014) Phylogeny, identification and nomenclature of the genus Aspergillus. Stud Mycol 78:141-173.

Singh C, Parmar RS, Jadon P, Kumar A (2017) Optimization of cultural conditions for production of antifungal bioactive metabolites by Streptomyces spp. isolated from soil. Int J Curr Microbiol App Sci 6(2): 386396.

Singh RP, Kumari P, Reddy CR (2015) Antimicrobial compounds from seaweeds-associated bacteria and fungi. Appl Microbiol Biotechnol 99(4): 1571-1586.

Sobolevskaya MP, Leshchenko EV, Hoai TP, Denisenko VA, Dyshlovoy SA, Kirichuk NN, Khudyakova YV, Kim NY, Berdyshev DV, Pislyagin EA, Kuzmich AS, Gerasimenko AV, Popov RS, von Amsberg G, Antonov AS, Afiyatullov SS (2016) Pallidopenillines: Polyketides from the alga-derived fungus Penicillium thomii Maire KMM 4675. J Nat Prod 79(12): 3031-3038.

Vandermolen KM, Raja HA, El-Elimat T, Oberlies NH (2013) Evaluation of culture media for the production of secondary metabolites in a natural products screening program. AMB Express 3(1): 71. doi: 10.1186/2191-08553-71.

Wang YN, Shao CL, Zheng CJ, Chen YY, Wang CY (2011) Diversity and antibacteial activities of fungi derived from the gorgonian Echinogorgia rebekka from the South China Sea. Mar Drugs 9(8): 1379-1390.

Zuccaro A, Schoch CL, Spatafora JW, Kohlmeyer J, Draeger S, Mitchell JI (2008) Detection and identification of fungi intimately associated with the brown seaweed Fucus serratus. Appl Environ Micobiol 74(4): 931-941.

\section{ẢNH HƯởNG CỦA ĐIỀU KIỆN LÊN MEN SINH HOẠT TÍNH KHÁNG SINH CỦA CHỦNG VI NẤM BIỄN ASPERGILLUS FLOCCULOSUS 01NT.1.1.5}

Phan Thị Hoài Trinh ${ }^{1,3}$, Ngô Thị Duy Ngọc ${ }^{1}$, Võ Thị Diệu Trang ${ }^{1}$, Phí Quyết Tiến ${ }^{2,3}$, Bùi Minh Lý ${ }^{1,3}$, Trần Thị Thanh Vân ${ }^{1,3}$, Phạm Đức Thịnh ${ }^{1,3}$, Phạm Trung Sản ${ }^{1,3}$

${ }^{1}$ Viện Nghiên cứu và Ứng dụng Công nghệ Nha Trang, Viện Hàn lâm Khoa học và Công nghệ Việt Nam

${ }^{2}$ Viện Công nghệ sinh học, Viện Hàn lâm Khoa học và Công nghệ Việt Nam

${ }^{3}$ Học viện Khoa học và Công nghệ, Viện Hàn lâm Khoa học và Công nghệ Việt Nam

\section{TÓM TẮT}

Sự sinh tổng hợp các hợp chất có hoạt tính kháng khuẩn tạo ra bởi vi nấm biển phụ thuộc lớn vào điều kiện sinh trưởng của chúng. Việc làm rõ vai trò của điều kiện nuôi cấy trong quá trình tổng hợp các chất chuyển hóa sẽ thuận lợi cho các nghiên cứu về hợp chất từ vi sinh vật. Trong nghiên cứu này, ảnh hưởng của điều kiện nuôi cấy bao gồm thời gian nuôi cấy, $\mathrm{pH}$ ban đầu và độ mặn của môi trường lên hoạt tính kháng khuẩn cũng như quá trình tạo chất chuyển hóa thứ cấp của chủng vi nấm biển 01NT.1.1.5 đã được điều tra. Chủng vi nấm 01NT.1.1.5 được phân lập từ bọt biển Stylissa sp. thu thập tại vịnh Nha Trang, có hoạt tính kháng khuẩn phổ rộng đối với các chủng vi sinh vật kiểm định Bacillus cereus ATCC 11778, Escherichia coli ATCC 25922, Staphylococcus aureus ATCC 25923, Listeria monocytogenes ATCC 19111, Streptococcus 
faecalis ATCC 19433 và Candida albicans ATCC 10231. Căn cứ vào đặc điểm hình thái và phân tích trình tự 28S rDNA, chủng vi nấm được xác định là Aspergillus flocculosus. Kết quả nghiên cứu cho thấy hoạt tính kháng sinh và hàm lượng chất chuyển hóa đạt cao nhất khi chủng vi nấm được nuôi cấy trên môi trường gạo với thời gian 20 ngày, độ mặn và $\mathrm{pH}$ môi trường nuôi cấy ban đầu tối ưu là $35 \mathrm{~g} / \mathrm{L}$ và 6.0 . Nồng độ muối và $\mathrm{pH}$ ban đầu khác nhau có ảnh hưởng rõ rệt tới sinh trưởng và hoạt tính kháng khuẩn của chủng $A$. flocculosus 01NT.1.1.5. Cụ thể, dịch chiết của chủng vi nấm chỉ thể hiện hoạt tính kháng C. albicans khi được nuôi trong môi trường có độ mặn $30-35 \mathrm{~g} / \mathrm{L}$ và $\mathrm{pH}$ ban đầu 4.0-8.0. Các kết quả chứng minh rằng độ mặn và $\mathrm{pH}$ ban đầu cùng với thời gian lên men là những yếu tố quan trọng quyết định hoạt tính kháng khuẩn và sự sản sinh các chất chuyển hóa thứ cấp của chủng vi nấm biển.

Tù̀ khóa: Aspergillus flocculosus, hoạt tính kháng khuẩn, điều kiện nuôi cấy, vi nấm biển 